\title{
Egg production by the calanoid copepod Acartia tonsa in the mesohaline Chesapeake Bay: the importance of food resources and temperature
}

\author{
Jacques R. White*, Michael R. Roman
}

Horn Point Environmental Laboratory, Center for Environmental and Estuarine Studies, The University of Maryland System, PO Box 775, Cambridge, Maryland 21613, USA

\begin{abstract}
Egg production of Acartia tonsa females was measured simultaneously with grazing and other biological and physical parameters in the mesohaline portion of Chesapeake Bay, USA, during periods of 1987 and 1988. We hypothesized that egg production would be related to food abundance in situ, depending principally on phytoplankton in spring and microzooplankton in summer. Step-wise multiple regression analysis indicated that egg production (female $\mathrm{C} \mathrm{d}^{-1}$ ) was significantly correlated with temperature (parabolic transform), protozoan microplankton biomass, and the $C: N$ ratio of suspended particulate matter. Egg production was not correlated with any measures of phytoplankton biomass, production or ingestion. Egg production was significantly higher at night while there was no observed diel trend in ingestion of phytoplankton by $A$. tonsa. The amount of carbon ingested as phytoplankton was adequate to support calculated growth and metabolic requirements of $A$. tonsa females roughly half the time. Carboy experiments were used to compare the relative amounts of phytoplankton and microzooplankton carbon ingested by $A$. tonsa in the bay on 2 occasions in May and August of 1988. Copepod carbon-specific ingestion rates on phytoplankton were low $15.5 \mu \mathrm{g} \mathrm{C}(\mathrm{mg}$ $\left.\mathrm{C}^{-1} \mathrm{~h}^{-1}\right]$ in May, but relatively high on microzooplankton $\left.[22.7 \mu \mathrm{g} \mathrm{C} \mathrm{(mg} \mathrm{C})^{-1} \mathrm{~h}^{-1}\right]$. In August, microzooplankton were ingested at lower rates compared to May $\left[7.2 \mu \mathrm{g} \mathrm{C}(\mathrm{mg} \mathrm{C})^{-1} \mathrm{~h}^{-1}\right]$ but phytoplankton were ingested at much higher rates $\left[48.2 \mu \mathrm{g} \mathrm{C}\left(\mathrm{mg} \mathrm{C}^{-1} \mathrm{~h}^{-1}\right]\right.$. For both experiments, the total $\mathrm{C}$ ingested as phytoplankton and microzooplankton was sufficient to balance the calculated respiration and measured egg production requirements of $A$. tonsa females. From these results we conclude that microzooplankton can provide an important food source for estuarine copepods, and that temperature and microzooplankton rather than phytoplankton abundance may be the best indicators of $A$. tonsa reproductive potential in Chesapeake Bay
\end{abstract}

\section{INTRODUCTION}

Reproduction rate of copepods has been shown to depend on temperature (McLaren 1965, Heinle 1969, Paffenhöfer \& Harris 1976), food quantity (Huntley \& Boyd 1984) and the quality of available food (Checkley $1980 \mathrm{a}, \mathrm{b})$. The relative importance of these factors in controlling copepod growth and production can vary between species and location, and it may depend on recent feeding history. The goal of this study was to determine which factors control egg production of

\footnotetext{
- Present address: Smithsonian Environmental Research Center, Smithsonian Institution, PO Box 28, Edgewater, Maryland 21037, USA
}

the dominant copepod species Acartia tonsa in Chesapeake Bay, USA, during summer.

Egg production by adult female copepods has been used as an index of growth since it is a relatively simple measurement (Marshall \& Orr 1955). Egg production of Acartia tonsa has been related to food abundance and quality (Dagg 1977, Cahoon 1981, Durbin et al. 1983, Kiorboe 1989) and temperature (Sekiguchi et al. 1980, Uye 1981) in laboratory studies, and the concentration of chl a $>10 \mu \mathrm{m}$ (Bellantoni \& Peterson 1987), temperature and the amount of particulate nitrogen (Ambler 1982) in situ. Because egg production is an integrated response to recent feeding history, it may be more closely related to concentrations of food measured 12 to $24 \mathrm{~h}$ prior to egg laying (Stearns et al. 1989). 
Protozoan microplankton are a potentially important food source in the size range of prey items selected by copepods. In laboratory experiments, copepods clear planktonic ciliates and heterotrophic dinoflagellates at rates equal to or greater than algae (Stoecker \& Capuzzo 1990, and references therein). In addition, microzooplankton have been shown to provide up to $50 \%$ of the $\mathrm{C}$ ingested by Acartia tonsa (Gifford \& Dagg 1988. Tiselius 1989). However, no information is presently available concerning the effect of microzooplankton ingestion on copepod egg production.

Chesapeake Bay is characterized by spring blooms of relatively large-cell phytoplankton species (principally diatoms and large flagellates), followed in summer by water column stratification, increasing water temperature, and high rates of primary production by phytoplankton $<20 \mu \mathrm{m}$ in diameter (Malone et al. 1986, McCarthy et al. 1974). Under these conditions, we hypothesized that copepods would feed on larger phytoplankton cells available in the spring, and on microzooplankton when small algae are more abundant during summer.

To further understand the factors that control copepod production in estuaries, we present results from measurements of egg production, ingestion of phytoplankton and microzooplankton by the copepod Acartia tonsa, and measurements of hydrographic parameters taken 2 successive years in Chesapeake Bay.

\section{METHODS}

Egg production experiments. Shipboard egg production experiments with Acartia tonsa females were carried out during cruises to the mesohaline reach of Chesapeake Bay $\left(31^{\circ} 41^{\prime} \mathrm{N}, 64^{\circ} 15^{\prime} \mathrm{W}\right)$. Experiments were run on 4 dates from May to August 1987 and 9 dates spanning the period May to October 1988. Copepods used in the experiments were collected in a $200 \mu \mathrm{m}$ mesh, $0.5 \mathrm{~m}$ diameter plankton net fitted with a closed cod-end towed obliquely through the surface mixed layer. After the tow, cod-end contents were gently diluted and transferred into 21 plastic beakers. A. tonsa adult females were identified under a stereoscopic microscope (dim light for nighttime incubations) and 3 to 4 copepods were gently picked by pipet and placed into egg production chambers pre-filled with $200 \mu \mathrm{m}$ screened surface water. Chambers were then placed into an incubator containing flowing surface water (Fig. 1) for 2 consecutive $12 \mathrm{~h}$ (12 night: 12 day) or one $24 \mathrm{~h}$ incubation. Chambers containing only $200 \mu \mathrm{m}$ screened water were incubated along with treatment chambers to correct for eggs and small nauplii added with the water.
At the end of the experimental period, chambers were removed from the incubator and the water allowed to drain, concentrating copepods on the first mesh and eggs on the bottom mesh (Fig. 1). Both copepods and eggs were washed into sample jars with filtered bay water, the condition of females noted (immobile opaque individuals were considered dead and not included in egg production rate calculations), and the samples preserved in $5 \%$ buffered formalin. In the laboratory, adult female and egg length were determined using a microscope, digitizing pad and computer image-analysis system. Egg carbon was estimated using the conversion factor $0.0305 \mu \mathrm{g} \mathrm{C} \mathrm{egg}^{-1}$ (Ambler 1982). Female carbon was calculated from an equation derived by drying and weighing different stages of preserved Acartia tonsa (allowing for $30 \%$ shrinkage due to preservation in formalin) and assuming a carbon to dry weight ratio of 0.32 :

$$
C_{\mathrm{f}}=3.04\left(L^{1.551}\right)
$$

where $C_{\mathrm{f}}$ is the biomass in $\mu \mathrm{g} C$ female ${ }^{-1}$ and $L=$ length in $\mathrm{mm}\left(\mathrm{r}^{2}=0.64, \mathrm{SE}_{\text {slope }}=0.399\right)$.

Grazing experiments. Copepod grazing of phytoplankton was measured simultaneously during all egg production experiments. Copepods were collected as described above and 20 to 60 late-stage copepodites (Stages CIV to CVI) $>200 \mu \mathrm{m}$ gently transferred to six 11 polycarbonate bottles containing $200 \mu \mathrm{m}$ screened bay water. For experiments run in 1987, phytoplankton were pre-labelled for $1 \mathrm{~h}$ under fluorescent light with ${ }^{14} \mathrm{C}$-bicarbonate before adding copepods (Daro 1980,

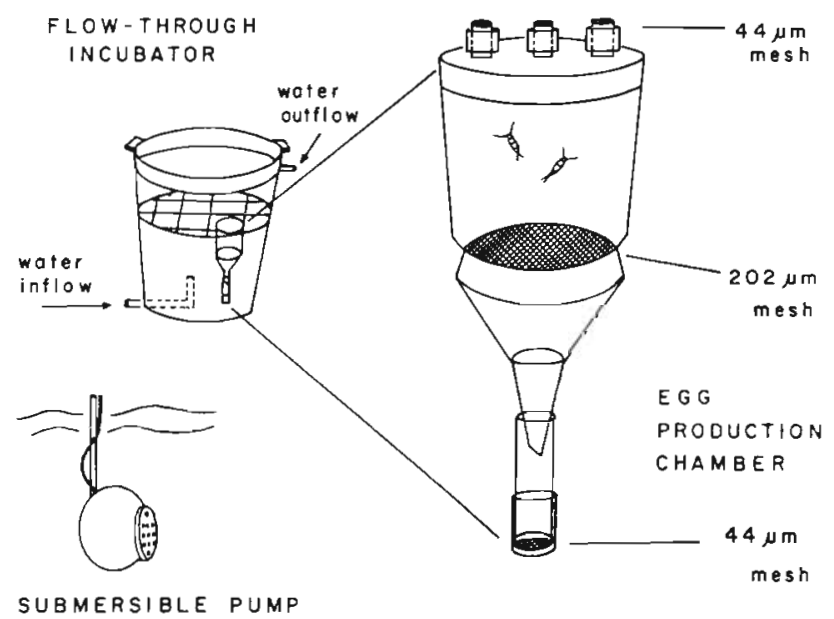

Fig. 1 Flow-through egg production system. Consists of a submersible pump with plastic impeller, $38 \mathrm{l}$ flow-through incubator with Tygon tubing chamber support, and egg production chambers constructed with $250 \mathrm{ml}$ Nalgene ${ }^{\mathscr{B}}$ polycarbonate filter funnels. Each chamber was fitted with a series of Nitex screens: $44 \mu \mathrm{m}$ on the top and bottom to retain eggs but allow water circulation and $202 \mu \mathrm{m}$ in the center separating adult females from eggs to reduce cannibalism 
Roman et al. 1988a). Once copepods were added, the bottles were placed in light (day) or dark (night) incubators with flow-through bay water. During 1988 phytoplankton were labelled after adding copepods (Daro 1978). A combination of ${ }^{3} \mathrm{H}$-methylamine and ${ }^{24} \mathrm{C}$ bicarbonate was added in daylight incubations while ${ }^{3} \mathrm{H}$-methylamine alone was used for dark incubations. ${ }^{3} \mathrm{H}$-methylamine is an ammonium analog taken up by phytoplankton in both light and dark (Balch 1985) which gives grazing rates similar to those obtained using ${ }^{14} \mathrm{C}$ bicarbonate ( $n=42, r^{2}=0.80$; White \& Roman 1991) This method eliminates the need to pre-label phytoplankton for nighttime feeding measurements.

Incubation times were short (15 to $60 \mathrm{~min}$ ) to reduce the transfer of label through herbivorous protozoa to copepods. After incubations, copepods were washed on a $200 \mu \mathrm{m}$ sieve with $0.22 \mu \mathrm{m}$ filtered bay water (FBW). Washed copepods and particulate matter were collected on 12.0 and $3.0 \mu \mathrm{m}$ polycarbonate filters respectively and their activity analyzed by liquid scintillation counting.

Clearance of phytoplankton [ml (mg copepod $\mathrm{C})^{-1} \mathrm{~h}^{-1}$ ] was calculated using the equations of Daro (1978), and converted to carbon ingested $(\mu \mathrm{g}$ phytoplankton $\mathrm{C}$ (mg copepod $\mathrm{C})^{-1} \mathrm{~h}^{-1}$ ] multiplying by phytoplankton carbon. A conversion factor for phytoplankton carbonto-chlorophyll of 51 was derived from the slope of a regression of total particulate organic carbon (POC) and $\mathrm{chl}$ a data collected during the study $[\mathrm{POC}=235+$ 51 (chl a), $\mathrm{n}=13, \mathrm{r}^{2}=0.48, \mathrm{SE}= \pm 16$ ]. In this calculation, we assumed: (1) the $y$-intercept represents nonphytoplankton carbon and (2) that this value varies independently of phytoplankton carbon (Strickland 1960, Banse 1977). Although this technique has been criticized in situations where the above assumptions are grossly violated (Banse 1977), we feel it provides a relatively efficient method of estimating phytoplankton carbon in situ. Notice that the ratio of 51 used by us is high, but in the range of values obtained for phytoplankton collected from natural populations and laboratory cultures (23 to 79 for mixed phytoplankton, Parsons et al. $1977 ; 30$ to 51 for Prorocentrum mariaelebouriae collected from Chesapeake Bay surface water, Harding \& Coats 1988).

Property measurements. Temperature, salinity and chl a depth profiles were determined using a pumpCTD-fluorometer system (Malone \& Ducklow 1990). To convert the fluorescence measurements to chl $a_{\text {, }}$ chlorophyll samples collected from the surface and bottom were analyzed by fluorometer after acetone extraction (Parsons et al. 1984). The chlorophyll size fraction $>10 \mu \mathrm{m}$ was determined by pre-screening water with $10 \mu \mathrm{m}$ Nitex. Particulate carbon and nitrogen were determined for pump water collected on precombusted GF/F glass fiber filters and measured by a
Control Data 240 HA analyzer. Microzooplankton (oligotrich and tintinnid ciliates and heterotrophic dinoflagellates $>10 \mu \mathrm{m}$ in diameter) were collected by Niskin bottle. The bottle contents were mixed by inverting the bottle and replicate $150 \mathrm{ml}$ whole water samples preserved in $2 \%$ glutaraldehyde. Subsample volumes were adjusted to settle 300 individual protozoa in settling chambers for enumeration with a Zeiss inverted microscope. Abundances of major taxonomic and size groupings were converted to biomass assuming spherical shape (cylindrical for tintinnids) and using literature-derived carbon to volume ratios (Table 1).

Carboy experiments. Experiments to estimate ingestion of microzooplankton by copepods were run on 2 cruises to the Chesapeake Bay during May 12 and August 11, 1988. Water was collected from the surface by bucket and gently reverse-filtered through a $64 \mu \mathrm{m}$ nitex screen into acid-washed, 101 polycarbonate carboys. Two control carboys contained only $64 \mu \mathrm{m}$ screened bay water. Two treatment carboys contained screened water with Stages CIV to CVI Acartia tonsa added at 2 to $5 \times$ in situ concentrations [37 (May) to 179 (August) $1^{-1}$; copepods were collected and separated as described above for egg production experiments]. Carboys were incubated for $24 \mathrm{~h}$ in flow-through deck incubators covered with neutral density screen (roughly $60 \%$ ambient light) during day and black plastic at night.

Time-series samples were collected by gently inverting the carboys several times to mix contents, and then pouring $1200 \mathrm{ml}$ from each into 2 I plastic beakers. One sample from each carboy was taken for chl a, particulate $\mathrm{C}$ and $\mathrm{N}$, and for microzooplankton abundance. Microzooplankton $>10 \mu \mathrm{m}$ in replicate subsamples were settled in Utermöhl chambers ( 7 to $15 \mathrm{ml}$ ), and

Table 1. Size categories and cell carbon used to calculate microzooplankton carbon ingested by late-stage Acartia tonsa copepodites in carboy experiments

\begin{tabular}{|c|c|c|c|c|}
\hline Category & $\begin{array}{c}\text { Cell } \\
\text { diameter } \\
(\mu \mathrm{m})\end{array}$ & $\begin{array}{c}\text { Conversion } \\
\text { factor }^{a} \\
\text { (fg } C \mu \mathrm{m}^{-3} \text { ) }\end{array}$ & $\begin{array}{c}\text { Mean cell } \\
\text { radius } \\
(\mu \mathrm{m})\end{array}$ & $\begin{array}{c}\text { Cell } \\
\text { carbon } \\
\left(\text { ng C cell }{ }^{-1}\right)\end{array}$ \\
\hline $\begin{array}{l}\text { Aloricate } \\
\text { ciliates }\end{array}$ & $\begin{array}{c}10-20 \\
20-50 \\
>50\end{array}$ & $200^{b}$ & $\begin{array}{r}7.5 \\
17.5 \\
30\end{array}$ & $\begin{array}{r}0.484 \\
6.151 \\
30.989\end{array}$ \\
\hline Tintinnids & $60 \times 20$ & $90^{c}$ & 10 & 1.831 \\
\hline $\begin{array}{l}\text { Heterotrophic } \\
\text { dinoflagellates }\end{array}$ & $\begin{array}{c}10-20 \\
>20\end{array}$ & $120^{d}$ & $\begin{array}{r}9 \\
20\end{array}$ & $\begin{array}{l}0.844 \\
9.266\end{array}$ \\
\hline \multicolumn{5}{|c|}{$\begin{array}{l}{ }^{a} \text { Conversion factors were obtained from: }{ }^{b} \text { Putt \& Stoecker } \\
\text { (1989); " Heinbokel (1978); d Strathmann (1967). Carbon } \\
\text { conversions were corrected for shrinkage due to preserva- } \\
\text { tion with } 2 \% \text { glutaraldehyde (Choi \& Stoecker } 1989 \text { ) }\end{array}$} \\
\hline
\end{tabular}


enumerated with an inverted microscope. Clearance rate $\left[\mathrm{ml}(\mathrm{mg} \text { copepod } \mathrm{C})^{-1} \mathrm{~h}^{-1}\right]$ was calculated by integrating the average change in cell density for the 2 replicate treatment carboys over all time periods, and correcting for growth of prey in control carboys (Frost 1972). Carbon ingested [ $\mu \mathrm{g} \mathrm{C}$ ( $\operatorname{mg}$ copepod $\mathrm{C}^{-1} \mathrm{~h}^{-1}$ ] was calculated from clearance rates and estimates of biomass for each functional size category of microzooplankton (Table 1)

\section{RESULTS}

\section{Egg production}

Egg production rate was variable both within and between sample dates, and only the highest and lowest measured rates were significantly different $(95 \%$ confidence level; Fig. 2). Rates did not vary linearly with temperature or phytoplankton carbon in either year, but did track microzooplankton carbon $>20 \mu \mathrm{m}$ during 1988. These results are supported by separate simple least squares regression analyses of egg production against individual environmental parameters (nontransformed), with only the regression model containing microzooplankton significant (Table 2).

Because biological processes often respond to changes in environmental parameters non-linearly, we examined the relationship between egg production and transformed field data. Egg production and temperature data show that these rates generally increased with temperature up to $27^{\circ} \mathrm{C}$, but were reduced at higher temperatures (Fig. 2) indicating a polynomial or curved function may better represent the relationship between them. In addition, egg pro-

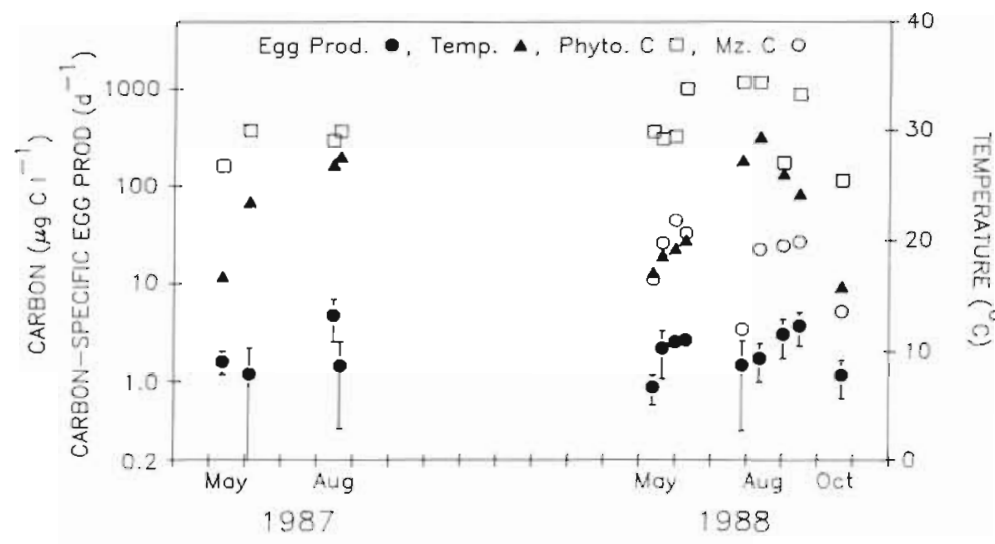

TIME OF YEAR

Fig. 2. Temperature, phytoplankton and microzooplankton carbon (1988 only) and egg production rate of Acartia tonsa females plotted against time for summer 1987 and summer and fall of 1988 in Chesapeake Bay. Error bars for egg production represent $95 \%$ confidence limits of mean
Table 2. Acartia tonsa. Results of simple least squares regression of copepod egg production vs different environmental parameters measured simultaneously in Chesapeake Bay during 1987 and 1988. Variables consist of either raw or transformed data with operation shown: $T=$ temperature $\left({ }^{\circ} \mathrm{C}\right)_{i}$ whl chl $=$ chl $a$ from GF/F filters $\left(\mu \mathrm{gl} \mathrm{l}^{-1}\right) ; \mathrm{chl}>10=\mathrm{chl} a$ $>10 \mu \mathrm{m}\left(\mu \mathrm{g} \mathrm{l}^{-1}\right) ; \mathrm{mz}=$ microzooplankton carbon $>10 \mu \mathrm{m}$ $\left(\mu \mathrm{gl}^{-1}\right) ; C: N=$ carbon-to-nitrogen ratio of suspended particulate matter $S=$ stratification parameter $\left[\Delta \sigma_{\mathrm{L}}\right.$, muxed layer (mixed depth $\left.)^{-1}\right] ; I_{p}=$ ingestion of phytoplankton $[\mu \mathrm{g}$ phytoplankton $C(\text { mg copepod } C)^{-1} h^{-1}$ ]; $a T-b T^{2}=$ polynomial equation relating temperature and egg production; $n=$ no. of observations

\begin{tabular}{|lrcl|}
\hline Variable & $\mathrm{n}$ & $\mathrm{r}^{2}$ & $\mathrm{p}$-value \\
\hline$T$ & 13 & 0.06 & 0.41 \\
whl chl & 13 & 0.02 & 0.61 \\
$\mathrm{chl}>10$ & 13 & 0.01 & 0.69 \\
$\mathrm{mz}$ & 9 & 0.51 & $0.03^{\cdot}$ \\
$\mathrm{C}: \mathrm{N}$ & 13 & 0.14 & 0.20 \\
$\mathrm{~S}$ & 13 & 0.00 & 0.96 \\
$I_{\mathrm{p}}$ & 13 & 0.09 & 0.31 \\
$a T-6 T^{2}$ & 9 & 0.73 & $0.003 \cdot$ \\
$\log \mathrm{chl}$ & 9 & 0.04 & 0.62 \\
$\log \mathrm{mz}$ & 9 & 0.50 & $0.03 \cdot$ \\
$\log I_{\mathrm{p}}$ & 9 & 0.02 & 0.72 \\
$\cdot$ Significant $\mathrm{r}^{2}$, & $\cdots$ & highly significant $\mathrm{r}^{2}$ & \\
\hline
\end{tabular}

duction should also have a nonlinear response to increases in food concentration, reaching a maximum level at some critical concentration and not increasing beyond that (Checkley 1980b, Kiørboe et al, 1985). Transformations used to linearize the relationship between egg production and independent variables are shown in Table 2 .

Some of the variables considered in the single variable regression analyses may act simultaneously (but independently) to affect egg production. Therefore, we used step-wise multiple linear regression analysis to examine the effects of several variables on egg production at once Since microzooplankton were not collected during 1987, only data from the 9 sampling dates in 1988 were included in the multiple regression analysis.

The multiple linear regression model utilizing transformed temperature data gave results different from the single variable regression analyses. Significant variables were selected by step-wise factor analysis (Sokal \& Rolf 1981). The polynomial temperature function accounted for the most variation in egg production, although both microzooplankton biomass and $\mathrm{C}: \mathrm{N}$ ratio were also significant (Table 3). Egg production was not closely related. to chlorophyll in either the simple or multiple regression analysis 
Table 3. Acartia tonsa. Results of multiple linear regression of copepod egg production vs environmental parameters measured simultaneously in Chesapeake Bay during 1988. Variables consist of raw and transformed data with operations shown; variable symbols are the same as Table 2. n: no of observations; significance level and $t$-values are of coefficients for individual parameters. Results of ANOVA are shown for model

\begin{tabular}{|c|c|c|c|c|}
\hline \multicolumn{5}{|c|}{ Regression } \\
\hline Constant & & -4.41 & -3.48 & $0.0176^{\circ}$ \\
\hline$a T-b T^{2}$ & 9 & 0.62 & 4.15 & $0.0089 \cdot$ \\
\hline $\log m z$ & 9 & 0.45 & 3.68 & $0.0143^{\circ}$ \\
\hline$C: N$ & 9 & -0.10 & -2.5 & $0.0496^{\circ}$ \\
\hline \multicolumn{5}{|c|}{ ANOVA } \\
\hline Source & df & $r^{2}$ (adj.) & F-ratio & p-value \\
\hline Model & 3 & 0.89 & 22.70 & $0.0024^{\cdots}$ \\
\hline
\end{tabular}

\section{Ingestion of phytoplankton}

The weight-specific ingestion rate of phytoplankton by copepods $\left[I_{p}=\mu \mathrm{g}\right.$ phytoplankton $C$ (mg copepod $\mathrm{C}^{-1} \mathrm{~h}^{-1}$ ] varied by season with rates generally high during summer, but low during May of both years and October 1988 (Fig. 3). Variability was highest between late May and early June 1988 (Fig. 3). Unlike egg production, $\log I_{\mathrm{p}}$ was directly correlated with temperature $\left(r^{2}=0.67, p<0.01\right)$ and therefore could not be considered in the multiple regression model. However, results of partial correlation analysis (Sokal \& Rolf 1981) show that $\log I_{\mathrm{p}}$ accounts for little if any of the

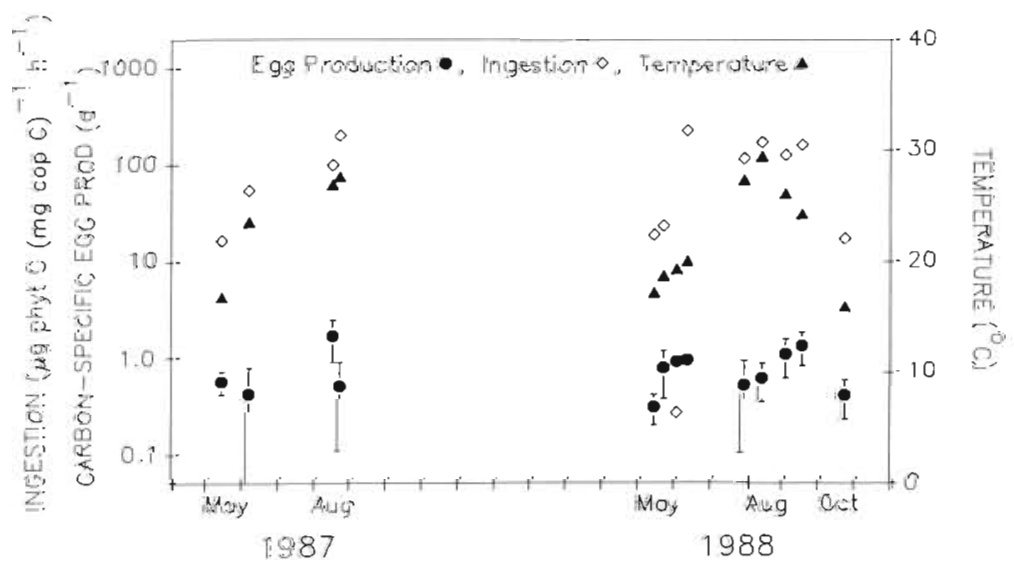

TIME OF YEAR

Fig. 3. Temperature, ingestion of phytoplankton C, and egg production rate of Acartia tonsa females plotted against time for summer 1987 and summer and fall 1988 in Chesapeake Bay. Error bars for egg production represent $95 \%$ confidence limits of mean variation in egg production when considered with the transformed temperature data (partial correlation coefficients: $a T-b T^{2}=0.66, \log I_{\mathrm{p}}=0.16, \mathrm{n}=11$ ). Taken together with the results of the regression analyses, these findings indicate that phytoplankton abundance and ingestion are poor predictors of Acartia tonsa egg production in Chesapeake Bay.

Egg production (EP) was not closely correlated with $I_{p}$ as a function of time of day or depth in the water column. We made separate night and day measurements of egg production together with $I_{\mathrm{p}}$ on 8 occasions (Fig. 4). Although egg production was significantly higher at night on 7 of 8 dates sampled, the ratio of $I_{\mathrm{p}}$ day: $I_{\mathrm{p}}$ night was variable, and frequently there was no diel difference in $I_{p}$ (Fig. 4A). Egg production was better correlated with $I_{\mathrm{p}}$ measured $12 \mathrm{~h}$ previously (i.e. EP night vs $\log I_{p}$ day, $r^{2}=0.69$ ) than with $I_{\mathrm{p}}$ measured simultaneously (i.e. EP night vs log $I_{p}$ night, $r^{2}=0.41$ ), indicating a time lag between ingestion and egg production. For the same dates, egg production was poorly correlated with chlorophyll measured both simultaneously $\left(r^{2}=0.12\right)$ and $12 \mathrm{~h}$ previously $\left(\mathrm{r}^{2}=0.05\right)$.

On May 19, 1988, ingestion and egg production were measured with Acartia tonsa and water collected from both $10 \mathrm{~m}$ in the chlorophyll maximum $(\mathrm{CM}=$ $22.3 \mu \mathrm{g} \mathrm{chl} \mathrm{al}^{-1}$ ) and the surface (CM $\left.=10.9 \mu \mathrm{g} \mathrm{chl} \mathrm{a}^{-1}\right)$. Egg production was significantly higher (outside $95 \%$ confidence limits; Fig. 5) in copepods collected from, and incubated in, CM water compared with surface water. In contrast $I_{p}$ was not significantly different $(p=0.05)$ between surface and CM water (Fig. 5).

To determine whether ingestion of phytoplankton could balance the carbon requirements of Acartia tonsa females during our study, we compared temperature-specific respiration and growth rate (defined as measured egg production) with measured ingestion rates (Table 4). Growth rate was calculated using the equation:

$$
G=E P \times C_{f}
$$

where $G=$ growth rate $\left(\mu \mathrm{g} C\right.$ female $\left.{ }^{-1} \mathrm{~d}^{-1}\right)$; $E P=$ fraction of female carbon produced as eggs per day $\left(\mathrm{d}^{-1}\right)$; and $C_{\mathrm{f}}=$ female carbon ( $\mu \mathrm{g} C$ female $\left.{ }^{-1}\right)$. Carbon demand due to respiration was estimated for Acartia tonsa using a relationship derived from Conover (1956: Fig. 20):

$$
R=C_{i} K(0.543 T+0.25)
$$

where $R=$ respired carbon $\left(\mu \mathrm{g} C\right.$ female $e^{-1}$ $\left.\mathrm{d}^{-1}\right) ; T=$ temperature $\left({ }^{\circ} \mathrm{C}\right)$; and $K$ includes factors converting oxygen volume and 

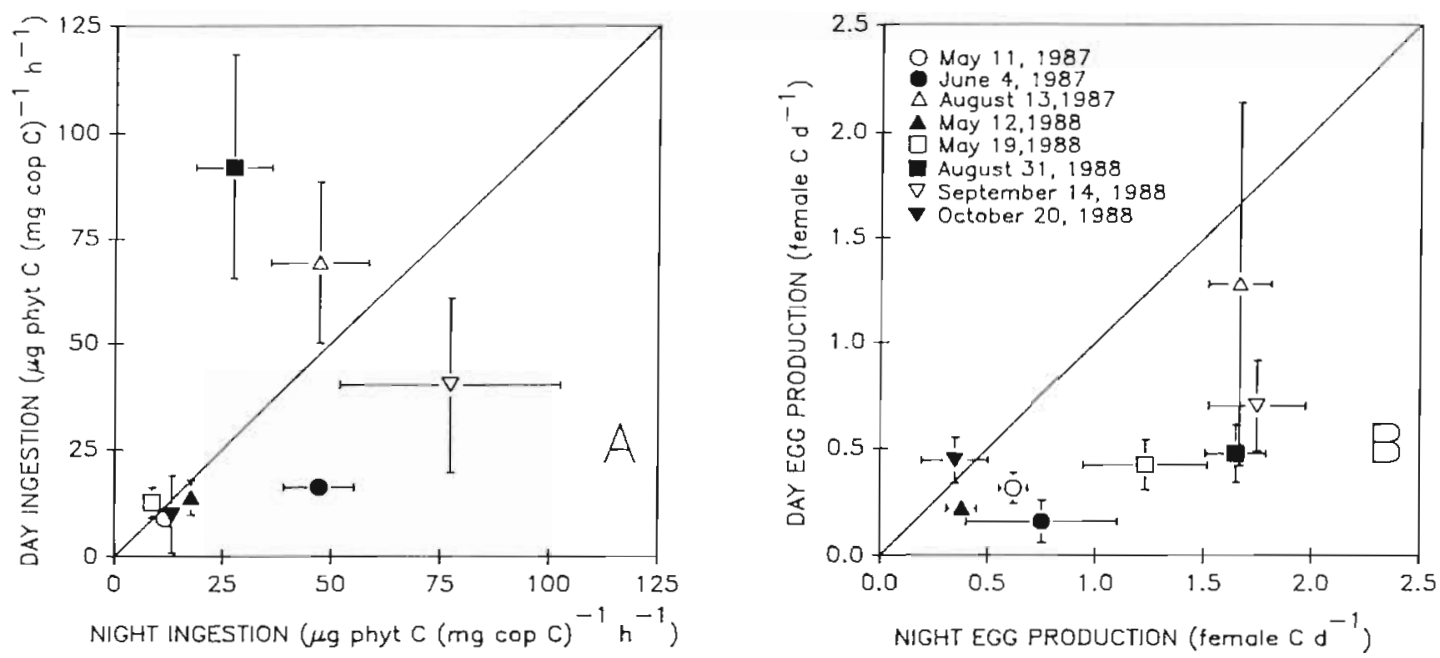

Fig. 4. Acartia tonsa. Comparison of nighttime and daytime rates of (A) phytoplankton ingestion and (B) egg production by adult female copepods measured on different dates in Chesapeake Bay. Error bars = SE of mean

dry weight to carbon units $\left(12 \mathrm{mg} \mathrm{C} / 22.4 \mathrm{ml} \mathrm{O}_{2}\right.$ Parsons et al. 1977) and hours to days. The respiratory quotient is assumed to equal 1. Since female biomass did not differ by more than $21 \%$ during our study, respiration was treated as a simple linear, rather than logarithmic, function of biomass.

On roughly half of the sampling dates, ingestion of phytoplankton $\left(I_{p}\right)$ alone was not sufficient to meet the carbon requirements for growth and respiration of female Acartia tonsa $\left[I_{\mathrm{p}} /(G+R)<1.0\right]$. This shortfall occurred infrequently during summer, often in May of both years and during October 1988 (Table 4). Egestion was not measured, so ingestion rates used in the comparison were not corrected for assimilation efficiency. Therefore, actual carbon assimilated by $A$. tonsa to balance growth and metabolism may be 10 to $50 \%$ less than ingested (Kiørboe et al. 1985).

May 19,1988

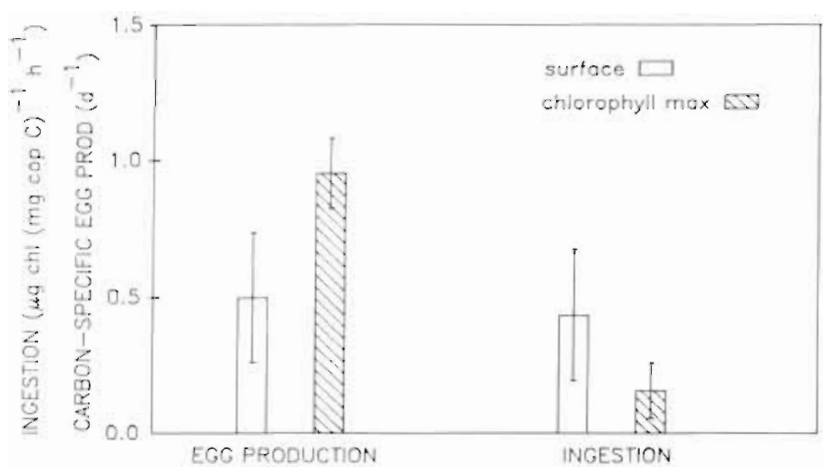

Fig. 5. Acartia tonsa. Differences in egg production and phytoplankton ingestion related to depth in Chesapeake Bay. Error bars represent $95 \%$ confidence limits

\section{Carboy experiments}

There was a clear difference between sample dates in the proportions of microzooplankton and phytoplankton consumed by late stage Acartia tonsa copepodites. Microzooplankton had high growth rates and were cleared at the highest rates in the carboys during the August experiments (Fig. 6). However, cell densities were higher initially in May (Fig. 6; $t=0 \mathrm{~h}$ ), while copepod densities in carboys were $3 \times$ higher in August, so that ingestion of microzooplankton by individual copepods was highest in May (Table 4). Phytoplankton accounted for only $19 \%$ of the carbon ingested by individual $A$. tonsa in May, when most of the carbon was ingested as microzooplankton (Table 4). In August, the reverse was true with over $80 \%$ of the carbon being ingested as phytoplankton and the remainder as microzooplankton. When ingestion of microzooplankton is considered together with phytoplankton, total carbon ingested by $A$. tonsa females exceeds their calculated requirements for growth and respiration (Table 4).

\section{DISCUSSION}

The environmental factor most closely correlated with egg production in our study was temperature. Our observation that a nonlinear polynomial function of temperature was more closely related to egg production than untransformed temperature data is interesting but not without precedent. Laboratory experiments have shown that egg production of Acartia hudsonica (Sekiguchi et al. 1980), A. clausi and A. steuri (Uye 1981), and A. tonsa (Heinle 1969, Ambler 1982) 
Table 4. Acartia tonsa. Individual growth, respiration and ingestion rates of copepod females collected in Chesapeake Bay. Growth $(G)$ was measured as egg production, respiration $(R)$ was estimated from temperature ( $T$ ) and body weight (see text) and ingestion of phytoplankton $\left(I_{\mathrm{p}}\right)$ and microzooplankton $\left(I_{\mathrm{nz} z}\right)$ by copepods was measured in shipboard experiments. Daily $C$ requirement is defined as $G+R$. The relation $I /(G+R)$ is an index of $C$ uptake vs requirement: assuming an $80 \%$ assimilation efficiency, a value $<1.25$ indicates $C$ deficit, $>1.25$ superfluous feeding

\begin{tabular}{|c|c|c|c|c|c|c|c|c|}
\hline Date & $\begin{array}{c}T \\
\left({ }^{\circ} \mathrm{C}\right)\end{array}$ & $G$ & $R$ & 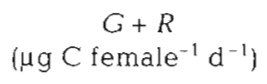 & $I_{\mathrm{p}}$ & $I_{\mathrm{mz}}$ & $\frac{I_{\mathrm{p}}}{(G+R)}$ & $\frac{\left(I_{\mathrm{p}}+I_{\mathrm{mz}}\right)}{(G+R)}$ \\
\hline \multicolumn{9}{|l|}{1987} \\
\hline May 12 & 16.8 & 1.16 & 0.70 & 1.86 & 0.69 & - & 0.37 & - \\
\hline Jun 4 & 23.5 & 0.67 & 0.98 & 1.65 & 2.26 & - & 1.37 & - \\
\hline Aug 14 & 26.9 & 2.07 & 0.90 & 2.97 & 3.35 & - & 1.13 & - \\
\hline Aug 20 & 27.6 & 0.68 & 0.93 & 1.61 & 6.86 & - & 4.26 & - \\
\hline \multicolumn{9}{|l|}{1988} \\
\hline May 12 & 17.1 & 0.64 & 0.72 & 1.36 & 0.28 & 1.15 & 0.58 & 1.05 \\
\hline May 20 & 18.7 & 1.58 & 0.80 & 2.37 & 0.99 & - & 0.42 & - \\
\hline May 31 & 19.3 & 1.89 & 0.81 & 2.71 & 0.01 & - & 0.01 & - \\
\hline Jun 9 & 20.0 & 1.91 & 0.82 & 2.73 & 9.20 & - & 3.37 & - \\
\hline Jul 27 & 27.2 & 1.06 & 1.12 & 2.18 & 4.71 & - & 2.16 & - \\
\hline Aug 11 & 29.4 & 1.21 & 1.20 & 2.41 & 2.40 & 0.36 & 0.99 & 1.15 \\
\hline Aug 31 & 26.0 & 2.01 & 0.98 & 2.99 & 4.69 & - & 1.57 & - \\
\hline Sep 14 & 24.2 & 2.30 & 0.89 & 3.19 & 5.82 & - & 1.83 & - \\
\hline Oct 20 & 15.8 & 0.71 & 0.64 & 1.35 & 0.68 & - & 0.50 & - \\
\hline
\end{tabular}
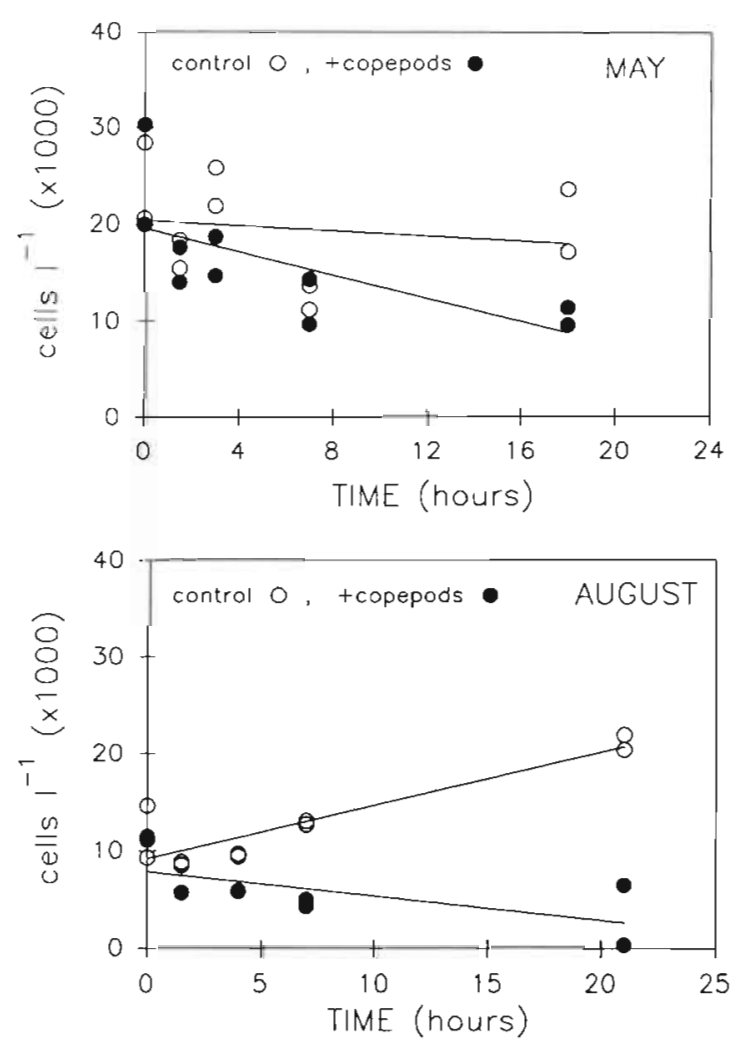

Fig. 6. Time series showing microzooplankton cell counts (ciliates and flagellates) from carboy experiments. Initial counts $(t=0 \mathrm{~h})$ are not included in linear regression since cell numbers decreased in all treatments over first hour. Positive slope indicates net increase in cell numbers increased with temperature to some maximum level and then declined rapidly at higher temperatures. For A. tonsa, Heinle (1969) found reduced growth rates at temperatures $>30^{\circ} \mathrm{C}$ and results from Ambler (1982: Fig. 8) show a steady decrease in egg production with increasing temperature above $20^{\circ} \mathrm{C}$.

In contrast to egg production, ingestion of phytoplankton tracked temperature directly with the highest values occurring at the highest temperatures. The relationships between temperature, measured egg production and ingestion rates, and estimated respiration rate are summarized for this study in Fig. 7. In general, egg production and respiration exceeded ingestion of phytoplankton at low temperatures, while ingestion was in excess of demand at high temperatures. For lower temperatures, the apparent carbon deficit is probably made up by ingestion of microzooplankton (as it was during May of 1988) or detritus (Roman 1984). At temperatures above $25^{\circ} \mathrm{C}$, the decoupling of ingestion and egg production may result from damaging effects of elevated temperature on enzymes or alteration of the viscosity of lipids involved in oogenesis (Hochachka \& Somero 1984). This should result in a redirection of ingested carbon towards respiration, a condition not satisfied by Eq. (3) (Fig. 7). Respiration does exceed egg production at the highest temperatures observed, but not enough to account for measured ingestion (Fig. 7). If the assimilation efficiency of Acartia tonsa changes by less than a factor of 2 with increased temperature (Kiørboe et al. 1985), then a 


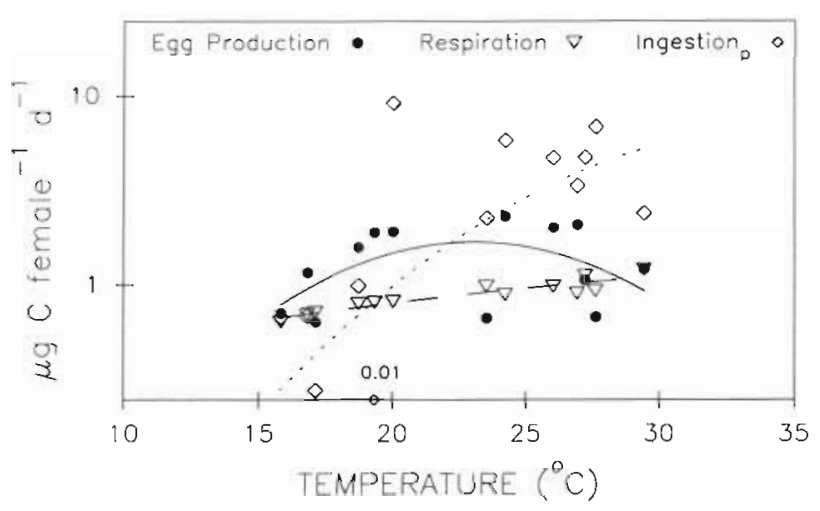

Fig. 7. Acartia tonsa. Measured egg production and ingestion rates, and estimated respiration rate vs ambient surface water temperature for copepods in Chesapeake Bay. Plots are bestfit of 2 nd-order polynomial functions

nonlinear, increasing relationship between respiration and temperature would be necessary to balance the decrease in egg production with increased ingestion

Another salient finding of our study was the poor correlation between Acartia tonsa egg production and chlorophyll. Ambler (1986) found a similar result for chlorophyll concentration and $A$. tonsa egg production in East Lagoon, Texas, USA. In contrast, Bellantoni \& Peterson (1987) found that $A$. tonsa egg production was closely correlated at times with chlorophyll $>10 \mu \mathrm{m}$ in Long Island Sound, USA, and Durbin et al. (1983) found that $A$. tonsa egg production was consistently limited by phytoplankton abundance in Narragansett Bay, USA, during summer. Several factors may have contributed to the poor correlation in our study. First, chlorophyll concentrations may have been above limiting levels throughout the study. Occasional blooms of phytoplankton cells that are unpalatable, noxious, very large and outside the preferred size range for $A$. tonsa, or cells of poor nutritional quality (high $C: N$ ratio or deficient lipid content) may also affect the correlation between egg production and chlorophyll. Finally, copepods may simply prefer microzooplankton, eating them when available instead of phytoplankton.

The chlorophyll concentration usually exceeded $7 \mu \mathrm{g} \mathrm{l}^{-1}$. Assuming a carbon to chlorophyll ratio of 51 (average over study), this is roughly equivalent to $360 \mu \mathrm{g}$ phytoplankton $\mathrm{C}^{-1}$, which is adequate for Acartia tonsa to maintain high levels of egg production (Ambler 1982, Kiørboe et al. 1985). This suggests that copepods should not have been food-limited in terms of phytoplankton abundance during most of our study.

Some of the measured chlorophyll may have come from cells too small or too big for copepods to handle efficiently (Nival \& Nival 1976, Berggreen et al. 1988). Pre-screening particles tended to increase the portion of chlorophyll in the $<10 \mu \mathrm{m}$ size fraction compared with values expected from cell counts of randomly selected samples. As a result, we do not have an accurate estimate of the size spectrum of chlorophyll experienced by copepods in situ. However, in August of both years we observed blooms (> $300 \mu \mathrm{g} \mathrm{C}^{-1}$ ) of the large phytoplankter Ceratium spp. $(200 \times 64 \mu \mathrm{m})$ in the bay. In the carboy experiment of August 12, 1988, these cells had higher apparent growth rates in carboys containing copepods compared with controls, indicating that copepods were not ingesting this species. These cells may be too large for Acartia tonsa to ingest, a factor which might help explain why Ceratium bloom in the bay.

Alternatively, some phytoplankton species may be unpalatable to copepods because they contain noxious substances which are repulsive or poisonous (Verity \& Smayda 1989, Uye \& Takamatsu 1990). Verity \& Smayda (1989) showed that adult Acartia tonsa exhibit poor reproduction and survival in the presence of the prymnesiophyte Phaeocystis pouchetij. Blooms of brown-and red-tide phytoplankton occur during the summer in Chesapeake Bay (Van Valkenburg \& Flemer 1974), so occasionally some of the measured chlorophyll may have been unavailable for, or actually inhibited, ingestion and egg production by $A$. tonsa in the bay.

Variation in the nutritional quality of phytoplankton is another factor which influences copepod egg production. It has been shown that egg production of copepods is sensitive to the amount of nitrogen in their food (Checkley 1980a, Ambler 1986, Kiørboe 1989). It is possible that ingested cells were lacking protein and amino acids (Kiørboe 1989), or lipids (Ahlgren et al. 1990) essential for growth and egg production. Houde \& Roman (1987) showed that ingestion of Acartia tonsa increased with decreasing $\mathrm{C}: \mathrm{N}$ of ingested phytoplankton. The fact that ingested phytoplankton carbon occasionally exceeded the respiration and growth (egg production) requirements of $A$. tonsa by a factor of 2 to 4 during summer supports the possibility that phytoplankton were nutritionally poor at times. Results of the step-wise multiple regression analysis showed that $C: N$ ratio could account for a significant portion of the variation in egg production. The C: $\mathrm{N}$ ratio of bulk particulate matter was quite variable during the study (range: 5.1 to 8.4). Since measured $C: N$ should reflect the relative nitrogen content of available food (phytoplankton, microzooplankton, and detritus), the suite of available particles may have been more suitable to support egg production at certain times during our study.

The presence of microzooplankton may have enhanced the quality of the food available to copepods. It has been suggested that a diet rich in $\mathrm{N}$ may have a lower associated cost of digestion and assimilation 
(specific dynamic action) in Acartia tonsa, resulting in more ingested material available for growth (Kiørboe et al. 1985). Microzooplankton (ciliates and heterotrophic dinoflagellates) generally have a lower $\mathrm{C}: \mathrm{N}$ ratio than phytoplankton and may contain other chemical constituents such as fatty acids essential for copepod egg production (Stoecker \& Capuzzo 1990). Microzooplankton biomass was the only variable significantly related to egg production independent of temperature. Therefore, when the $\mathrm{C}: \mathrm{N}$ ratio of total particulate matter is low, and/or when microzooplankton are abundant, $A$. tonsa in Chesapeake Bay should respond by increasing production.

Analysis of Acartia tonsa carbon requirements showed that ingestion of phytoplankton alone provided an adequate source of nutrition during summer, but fell short of $A$. tonsa demand in May and October. Results of the May carboy experiment support this conclusion and indicate that ingestion of microzooplankton can provide the necessary carbon difference. This result was contrary to our expectation that copepods would feed primarily on diatoms during spring and shift their preference to microzooplankton during summer as the phytoplankton becomes dominated by smaller cells (McCarthy et al. 1974, Van Valkenburg \& Flemer 1974, Malone et al. 1986).

Acartia tonsa does not become dominant in Chesapeake Bay until May (Brownlee \& Jacobs 1987), after the spring bloom and during the 'bloom crash' when much of the phytoplankton biomass is located at depth (Malone et al. 1988). This coincides with a peak in the abundance of heterotrophic dinoflagellates at depth in the bay ( $E$. Lessard pers. comm.) and $A$. tonsa probably relies on this food resource in May. In support of this, we found higher $A$. tonsa egg production at depth in May, even though $I_{p}$ is higher in surface waters.

Since we did not measure $I_{\mathrm{mz}}$ in October, we do not know the source of extra nutrition supporting egg production then. It is possible that copepods rely on microzooplankton or detritus (Roman 1984) to make up the estimated carbon deficit occurring at that time.

Stearns et al. (1989) found a strong nocturnal signal for both egg production and ingestion of phytoplankton by Acartia tonsa in 2 different estuaries. They attributed strong nocturnal egg laying to an endogenous rhythm but could not separate it from ingestion. In contrast, egg production and ingestion of phytoplankton by $A$. tonsa were not closely linked in time during this study; egg production was usually higher at night while ingestion rate showed no consistent daynight pattern. The behavior may be linked to vertical migration patterns in Acartia which often migrate to surface waters at night (Tiselius 1988). A. tonsa vertically migrate in Chesapeake Bay under certain condi- tions (Roman et al. 1988b). The survival of nauplii may be enhanced if eggs are released and hatched in surface waters rather than at depth, especially during summer when deep waters of the bay are anoxic (Officer et al. 1984).

Egg production of Acartia tonsa in Chesapeake Bay is correlated with several factors that vary in relative importance with season. In summer, A. tonsa egg production appears to be inhibited when temperature exceeds $27^{\circ} \mathrm{C}$. At the other sampling times, egg production seems to be limited by a combination of temperature and the absence of high quality food, calling into question the usefulness of using simple sizefractionated chl a measurements to characterize potential food resources of $A$. tonsa (but see Bellantoni \& Peterson 1987). Microzooplankton are clearly important to A. tonsa production in May and probably provide a nutritional supplement, if not the primary source of carbon at other times in the bay. In Chesapeake Bay where potential food resources are often plentiful and temperature varies seasonally, A. tonsa egg production rates can be approximated to the first order using temperature alone. Accounting for more variation requires characterizing a number of subtle differences in the quality of their food environment.

Acknowledgements. This work was completed as part of a larger study examining the effects of anoxia on living resources in Chesapeake Bay. We are indebted to many people who freely offered their data and assistance. Temperature, CHN, pigment and primary productivity data were provided by $T$ Malone and biomass of microzooplankton in situ was provided by E. Lessard who along with C. Miller helped design the carboy experiments. Invaluable shipboard assistance was provided by A. Gauzens, J. Jensen, C. Miller, S. Pike and B. Wendler We also thank the captain and crew of the RV 'Aquarius' Finally, thanks are due to W. Coats, M. Dagg, H. Ducklow, M. Kemp, T Malone and 3 anonymous reviewers whose comments improved earlier drafts of this manuscript. This research was supported by a grant from NOAA/Sea Grant to M. Roman. CEES contribution no. 2329.

\section{LITERATURE CITED}

Ahlgren, G., Lundstedt, L., Brett, M., Forsberg, C. (1990). Lipid composition and food quality of some freshwater phytoplankton for cladoceran zooplanktoners. J. Plankton Res. 4: 809-818

Ambler, J. W. (1982). Influence of natural particle diets on egg laying and hatching success of Acartia tonsa in East Lagoon, Galveston, Texas. Ph.D. dissertation, Texas A \& M University

Ambler, J. W. (1986). Effect of food quantity and quality on egg production of Acartia tonsa Dana from East Lagoon, Galveston, Texas. Estuar. coast. Shelf Sci. 23: 183-196

Balch, W. M. (1985). Lack of an effect of light on methylamine uptake by phytoplankton. Limnol. Oceanogr. 30: 665-674 
Banse, K. (1977). Determining the carbon to chlorophyll ratio of natural phytoplankton. Mar. Biol. 41. 199-212

Bellantoni, D. C., Peterson, W. T. (1987). Temporal variability in egg production rates of Acartia tonsa Dana in Long Island Sound. J. exp. mar. Biol. Ecol. 107: 199-208

Berggreen, U., Hansen, B., Kiorboe, T (1988). Food size spectra, ingestion and growth of the copepod Acartia tonsa during development: implications for determination of copepod production. Mar. Biol. 99: 341-352

Brownlee, D. C., Jacobs, F. (1987). Mesozooplankton and microzooplankton in the Chesapeake Bay. In: Majumdar, S. K., Hall, L. W., Austin, H. M. (eds.) Contaminant problems and management of living Chesapeake Bay resources. Pennsylvania Academy of Science, Philadelphia, p. $217-269$

Cahoon, L. B. (1981). Reproductive response of Acartia tonsa to variations in food rations and quality. Deep Sea Res. 28A: $1215-1221$

Checkley, D. M. Jr (1980a). The egg production of a marine planktonic copepod in relation to its food supply: laboratory studies. Limnol. Oceanogr. 25: 430-446

Checkley, D. M. Jr (1980b). Food limitation of egg production by a marine, planktonic copepod in the sea off southern California. Limnol. Oceanogr. 25: 991-998

Choi, J. W., Stoecker, D. K. (1989). Effects of fixation on cell volume of marine planktonic protozoa. Appl. environ. Microbiol. 55: 1761-1765

Conover, R. J. (1956). Oceanography of Long Island Sound, 1952-1954: biology of Acartia clausi and A. tonsa. Bull. Bingham oceanogr. Coll. 15: 156-233

Dagg, M. (1977). Some effects of patchy food environments on copepods. Limnol Oceanogr. 22: 99-107

Daro, M. H. (1978). A simplified ${ }^{14} \mathrm{C}$ method for grazing measurements on natural planktonic populations. Helgoländer wiss. Meeresunters. 31: 241-248

Daro, M. H. (1980). Field study of the diel feeding of a population of Calanus finmarchicus at the end of a phytoplankton bloom, FLEX '76, 22 May-5 June. 'Meteor' Forsch.-Ergebn. Reihe A, No. 22: 123-132

Durbin, E. G., Durbin, A. G., Smayda, T, J., Verity, P. G. (1983). Food limitation of production by adult Acartia tonsa in Narragansett Bay, Rhode Island. Limnol. Oceanogr. 28: 1199-1213

Frost, B. W. (1972). Effects of size and concentration of food particles on the feeding behavior of the marine planktonic copepod Calanus pacificus. Limnol. Oceanogr. 18: 805-815

Gifford, D. J., Dagg, M. J. (1988). Feeding of the estuarine copepod Acartia tonsa Dana: carnivory vs herbivory in natural microplankton assemblages. Bull. mar Res. 43 $458-468$

Harding, L. W., Coats, D. W. (1988). Photosynthetic physiology of Prorocentrum mariae-lebouriae (Dinophyceae) during its subpycnocline transport in Chesapeake Bay J. Phycol. 24: 77-89

Heinle, D. R. (1969). Temperature and zooplankton. Chesapeake Sci. 10: 186-209

Heinbokal, J. F. (1978). Studies on the functional role of tintinnids in the southern California Bight 1 Grazing and growth rates in laboratory cultures. Mar. Biol. 47.177-189

Hochachka, P. W., Somero, G. N. (1984). Biochemical adaptation. University Press, Princeton

Houde, S. L., Roman, M. R. (1987). Effects of food quality on the functional ingestion response of the copepod Acartia tonsd. Mar. Ecol. Prog. Ser. 40: 69-77

Huntley, M., Boyd, C. (1984). Food-limited growth of marine zooplankton. Am. Nat. 124: 4.55-478

Kiørboe, T (1989). Phytoplankton growth rate and nitrogen content: implications for feeding and fecundity in a herbivorous copepod. Mar. Ecol. Prog. Ser. 55: 229-234

Kiørboe, T., Mohlenberg, F., Hamburger, K. (1985). Bioenergetics of the planktonic copepod Acartia tonsa: relation between feeding, egg production and respiration, and composition of specific dynamic action. Mar. Ecol. Prog. Ser. 26: 85-97

Malone, T C., Kemp, W. M., Ducklow, H. W., Bornton, W. R., Tuttle, J. H., Jonas, R. B. (1986). Lateral variation in the production and fate of phytoplankton in a partially stratified estuary. Mar. Ecol. Prog. Ser. 32: 149-160

Malone, T C., Crocker, L. H., Pike, S. E., Wendler, B. W (1988). Influence of river flow on the dynamics of phytoplankton production in a partially stratified estuary. Mar Ecol. Prog. Ser. 48: 235-249

Malone, T C., Ducklow, H. W. (1990). Microbial biomass in the coastal plume of Chesapeake Bay: phytoplanktonbacterioplankton relationships. Limnol. Oceanogr. 35 $296-312$

Marshall, S. M., Orr, A. P. (1955). Calanus finmarchicus food uptake, assimilation, and excretion in adult copepods. J. mar. biol. Ass. U.K. 34: 495-529

McCarthy, J. J., Taylor, W. R., Loftus, M. E. (1974) Significance of nanoplankton in the Chesapeake Bay estuary and problems associated with measurement of nanoplankton productivity. Mar. Biol. 24: 7-16

Mclaren, I. A. (1965). Some relationships between temperature and egg size, body size, development rate, and fecundity of the copepod Pseudocalanus. Limnol. Oceanogr. 10 $528-538$

Nival, P., Nival, S. (1976). Particle retention efficiencies of an herbivorous copepod. Acartia clausi (adult and copepodite stages): effects on grazing. Limnol. Oceanogr. 21: 24-38

Officer, C. B., Biggs, R. B., Taft, J. L., Cronin, L. E., Tyler, M. A., Boynton, W. R. (1984). Chesapeake Bay anoxia: origin, development, and significance. Science 223: 22-27

Paffenhöfer, G.-A., Harris, R. P. (1976). Feeding, growth and reproduction of the marine planktonic copepod Pseudocalanus elongatus Boeck. J. mar. Biol. Ass. U.K. 56: $327-344$

Parsons, T. R., Takahashi, M., Hargrave, B. (1977). Biological oceanographic processes, 2nd edn. Pergamon Press, New York

Parsons, T R., Maita, Y., Lalli, C. M. (1984). A manual of chemical and biological methods for seawater analysis. Pergamon Press, New York

Putt, M., Stoecker, D. K. (1989). An experimentally determined carbon to volume ration for marine ciliates from estuarine and coastal waters. Limnol. Oceanogr. 34: $1097-1103$

Roman, M. R. (1984). Utilization of detritus by the copepod Acartia tonsa. Limnol. Oceanogr. 24: 949-959

Roman, M. R., Ashton, C. A., Gauzens, A. L. (1988a). Day/ night differences in the grazing impact of marine copepods. Hydrobiologia 167/168: 21-30

Roman, M. R., Malone, I C., White, J. R. (1988b). Short-term variations in phytoplankton-zooplankton interactions in Chesapeake Bay. EOS 69: 1097

Sekiguchi, H., McLaren, I. A., Corkett, C. J. (1980). Relationship between growth rate and egg production in the copepod Acartia clausi hudsonica. Mar. Biol. 58: 133-138

Sokal, R. R., Rohlf, F. J. (1981). Biometry. Freeman, San Francisco

Stearns, D. E., Tester, P. A., Walker, R. L. (1989). Diel changes in the egg production rate of Acartia tonsa (Copepoda, Calanoida) and related environmental factors in two estuaries. Mar. Ecol. Prog. Ser. 52: 7-16 
Stoecker, D. K., Capuzzo, J. M. (1990). Predation on protozoa: its importance to zooplankton. J. Plankton Res. 12: 891-908

Strathmann, R. R. (1967). Estimating the organic carbon content of phytoplankton from cell volume or plasma volume. Limnol. Oceanogr. 2: 411-418

Strickland, J. D. H. (1960). Measuring the production of marine phytoplankton. Bull. Fish. Res. Bd Can. 122: 1-172

Tiselius, P. (1988). Effects of diurnal feeding rhythms, species composition and vertical migration on the grazing impact of calanoid copepods in the Skagerrak and Kattegat. Ophelia 28: 215-230

Tiselius, P. (1989). Contribution of aloricate ciliates to the diet of Acartia clausi and Centropages hamatus in coastal waters. Mar. Ecol. Prog. Ser. 56: 49-58

Uye, S. (1981). Fecundity studies of neritic calanoid copepods Acartia clausi Giesbrecht and A. steueri Smirnov: a simple

This article was presented by K. R. Tenore, Solomons,

Maryland, USA empirical model of daily egg production. J. exp. mar. Biol Ecol. 50: 255-271

Uye, S., Takamatsu, K. (1990). Feeding interactions between planktonic copepods and red-tide flagellates from Japanese coastal waters. Mar Ecol. Prog. Ser. 59: 97-107

Van Valkenburg, S. D., Flemer, D. A. (1974). The distribution and productivity of Nanoplankton in a temperate estuarine area. Estuar. coast. mar. Sci. 2: 311-322

Verity, P. G., Smayda, I J. (1989). Nutritional value of Phaeocystis pouchetii (Prymnesiophyceae) and other phytoplankton for Acartia spp. (Copepoda): ingestion, egg production, and growth of nauplii. Mar. Biol. 100: $161-171$

White, J. R., Roman, M. R. (1991). Measurement of zooplankton grazing using particles labelled in light and dark with [methyl- ${ }^{3} \mathrm{H}$ ] methylamine hydrochloride. Mar. Ecol. Prog. Ser. 71: 45-52

Manuscript first received: May 29, 1991

Revised version accepted: June 23, 1992 